\title{
HUNGARIAN IFRS IMPLEMENTATION FROM TAX PERSPECTIVE
}

\author{
Gábor Fehér \\ Éva Karai ${ }^{2}$
}

DOI: https://doi.org/10.31410/ITEMA.2020.159

\begin{abstract}
The influence of corporate income taxation on financial statements presented on a domestic accounting standards basis differ by countries in a wide range. Corporate income taxation in Hungary has a strong connection to the Hungarian Accounting Act. From 2016 it is prescribed or allowed for specific companies to present their financial statements on IFRS basis. The transition represented not only a challenge in the accounting system of the companies, but the state had to face new tasks because the taxation of IFRS companies had to meet the tax principle of horizontal equity and ensure the proper tax revenue. Research data arise from financial statements of Hungarian companies listed on the Budapest Stock Exchange. The average effective tax rate of Hungarian listed companies decreased after the transition. Temporary tax rules for IFRS companies were applied to reach the tax level of the companies that prepare their financial statements following the Hungarian Accounting Law. Authors compare the results with empirical findings of other European countries.
\end{abstract}

Keywords: IFRS, Corporate income taxation, Listed companies.

\section{INTRODUCTION}

I n Hungary, from January 2016 on a range of companies have the opportunity, and since 2017, the obligation to apply the International Financial Reporting Standards (IFRS) by preparing their separate financial statements. To prepare transition, reconciliation with the various areas affected, such as e.g. accounting, taxation, collection of statistical data, has started from the very outset (Molnár, 2015).

In Hungary, the calculation of corporate tax relies strongly on the information obtained in the course of the derivation of accounting profits; therefore, the taxation issues of transition to the IFRS had utmost importance. The member states of the European Union are of divergent views whether they approve or not the use of IFRS on the level of separate financial statement ${ }^{3}$ (Bíró, 2015). The Anglo-Saxon countries and those Central and Eastern European countries that have joined later the EU would allow the application of the IFRS for a much broader circle of companies. On the other hand, Germany, France and Austria, where taxation and accounting are traditionally closely related, would allow only for the narrowest circle prescribed in the IAS regulation to prepare their separate financial statements in conformity with the IFRS (Guggiola, 2010; Procházka and Molín, 2016).

Eotvos Lorand University Institut of Business Economics, 1088 Budapest, Rákóczi út 7, Hungary Eotvos Lorand University Institut of Business Economics, 1088 Budapest, Rákóczi út 7, Hungary nts/ias-regulation-use-of-options-overview_en.pdf (European Committee, 2019) 
The situation of the Central European countries and, among them, Hungary, is peculiar because so far as the relation between accounting and corporate taxation are concerned they are conventionally much closer to the stringent German approach; still, as regards the application of the IFRS they tend to be much more allowing and stand closer to the Anglo-Saxon practice. The more widespread the application of the IFRS becomes on the level of the member states, the more important it is to find out how can IFRS-based accounting be harmonised with taxation (Brüggemann et al., 2012; Cuzdriorean and Matis, 2012; Jacobs et al., 2005).

Several empirical studies have examined actual or theoretical corporate taxation in the member states with taxes computed according to the IFRS or local accounting principles (Eberhartinger \& Klostermann, 2007; Gavana et al., 2015; Haverals, 2007; Jirásková, 2013). However, partly due to the vast differences in the methodology of the studies the conclusions significantly differ in whether the introduction of the IFRS would result in tax deficit or tax surplus for the respective exchequers of the different member states. The doubt raised before the introduction of IFRS in Hungary, namely whether transition shall or not have any negative impact on taxation, coincide with these quite diverse empirical results (Mészáros, 2015).

\section{TAXATION OF IFRS COMPANIES}

In Hungary, the most significant of all taxes levied on profits is the corporate tax. Earlier all companies in Hungary calculated the corporate tax based on the profit before tax as per the local GAAP, but after the transition, IFRS companies declare their corporate tax on the PBT as per IFRS.

As at the transition the parties set as a goal the principle of fiscal neutrality (Molnár, 2015), it had to be achieved that the tax liabilities of the companies should be more or less the same irrespective of their accounting systems. To reach this goal, adjusting items were required (Borók, 2015), and finally, amendments to the tax act were adopted. Companies under the domestic accounting system use adjusting items for modifying the tax basis. These adjusting items arise from the different requirements of the Act on Accounting and the Corporate Tax Act. The IFRS companies need further adjusting items to balance the differences between accounts prepared according to the IFRS and the Act on Accounting.

In the preparatory phase, the proper level of tax revenue was also formulated as a requirement in the transition process. A minimum tax was applied to maintain the stability of state revenues. Accordingly, in the fiscal year of transition and the consecutive tax year companies shall pay a corporate tax at least the same that paid in the last fiscal year preceding transition. When the company, due to unfavourable economic processes, should pay a significantly lower amount of corporate tax than the amount paid before the transition, a special exemption can be applied.

The legislator tries to eliminate the above anomaly of the minimum tax by a temporary solution. If the corporate tax liability of the company as calculated according to the Hungarian accounting rules would be less than in the year before the transition, then it can lodge a special request for its tax liability to be established according to the acts on accounting. This remedy is therefore available only temporarily as the exemption can be requested only in the year of transition and the consecutive one. In that case, companies shall have a bookkeeping system that meets the requirements of both IFRS and Hungarian Accounting Act (hereinafter; Hungarian Accounting Standards, HAS). 
Companies that establish their tax liabilities from the profit before tax as per IFRS incorporate into their calculations the differences between the two accounting systems with the help of a multi-phase corporate tax calculation process. As the Hungarian accounting rules treat the changes in the equity in a way different from the IFRS, therefore these differences shall need to be adjusted. The accounting treatment of expenses and incomes shows differences in the two systems, either; so, these differences must be adjusted, too, still before the establishment of the adjusted pre-tax profit.

Adjusted PBT shall be further modified because of the differences stemming from the different approaches of the statutory provisions regulating accounting and taxation. This modification circle has impacts on several points on the tax expense of those applying the IFRS. The switch from HAS to IFRS causes transition differences which also have to be considered on this level. After the consideration of the previously mentioned tax base adjustments, companies determine the corporate tax, which can be reduced potentially by tax benefits.

\section{METHODOLOGY AND DATA}

In our study, we analysed data on the corporate taxes paid between 2016 and 2018 by companies transitioning to the IFRS in 2017. According to the data published by the Hungarian National Tax and Customs Authority in 2017 (NAV, 2017), 142 companies that have transitioned to IFRS and preparing their accounts thereunder have filed corporate tax returns. We have confined our study only to companies listed on the Budapesti Értéktőzsde (Budapest Stock Exchange) as of 01 January 2020. The reason for this is that listed public companies are the only well identifiable group, that were uniformly obliged to adopt the use of IFRS.

On 01 January 2020 shares of 43 companies were listed on the Budapest Stock Exchange. Among these companies, 35 were listed in both 2017 - at the date of the obligatory IFRS transition. So, these companies have data relevant for our study. We removed the data of an association of savings banks, as it transitioned to IFRS in 2019. As a result, the 34 enterprises taken into account in the study represent only $24 \%$ of the transitioning companies, but they collectively account for $67 \%$ of the cumulated pre-tax profits of all. Therefore, the changes that can be observed in the sample well represent trends in state revenues as a result of the transition.

As regards their legal forms, out of the 34 companies, 33 are public companies limited by shares and 1 is a European company. As regards their business, industrial production companies, services providers and financial firms have a more or less equal share among them, and there are a small number of real estate companies, one bank and one insurer among them.

In our studies, we examined data in the financial statements of the 34 companies above for the period between 2016 and 2018. Using these we have obtained for each year the actual effective tax rates by the help of formula 1 .

$$
\text { effective tax rate }=\frac{\text { Corporate tax for the year of assessment }}{\text { IFRS profit before taxation -Other profit taxes }}
$$

Thus, from the period before the transition, from among the financial statements prepared in 2016 as per Hungarian Act on Accounting those were taken into account that had a positive pre-tax result in 2016, and their profit and loss statement showed corporate tax expense. Thus, out of the pre-selected 34 companies, the data of 17 could be used regarding 2016. From FYs 2017 and 2018, i.e. the period after the transition, we have collected the corporate tax liability 
and the pre-tax profit in the IFRS financial statements. We have taken into account companies that had tax liabilities in the given years and a positive pre-tax result. Seventeen listed companies met these criteria in 2017, and 24 in 2018.

The IFRS income taxes differ from those computed as per the Hungarian Act on Accounting; therefore, they had to be adjusted. The Act on Accounting interprets only corporate tax as an income tax expense in the year of assessment. Several IFRS companies in Hungary classify local business tax and innovation tax as an income tax under IAS 12 and other companies present these tax types as other operating expenses, which is the right treatment on the basis of the local GAAP. In 2017 were 20 and in 201822 cases, where these taxes were treated as income taxes. We filtered them from the pre-tax profits.

Table 1. Accounting for "other income taxes" at the companies studied

\begin{tabular}{|l|c|c|}
\hline Year & $\mathbf{2 0 1 7}$ & $\mathbf{2 0 1 8}$ \\
\hline Accounted for as income tax & 21 & 23 \\
\hline Accounted for as other operating expense & 12 & 11 \\
\hline No data available/no IFRS FS & 1 & 0 \\
\hline Total & 34 & 34 \\
\hline
\end{tabular}

The average amount of the effective corporate tax could be determined from the effective corporate tax rates of the companies using formula 1 . The results of the calculations are summarised in Table 2.

Table 2. Rate of the average effective corporate tax

\begin{tabular}{|l|c|c|c|}
\hline & 2016 eff. CT & 2017 eff. CT & 2018 eff. CT \\
\hline Average effective corporate tax & $6.72 \%$ & $3.35 \%$ & $7.33 \%$ \\
\hline The cleaned average effective tax rate & $5.76 \%$ & $3.10 \%$ & $4.97 \%$ \\
\hline
\end{tabular}

The averages presented in the first row of Table 2 contain some extreme values that considerably distorted our results; we cleaned our database. As a result, we calculated the cleaned effective tax rates, in which the highest and the lowest effective tax rate values of the respective companies were not included. The cleaned average effective tax rates can be found in the last row of Table 2 . We have compared the data obtained with national tax authority data for IFRS taxpayers published by Tóth-Takács (2018).

Table 3. Computation of the corporate tax of companies using the IFRS in 2017 (data in HUF)

\begin{tabular}{|c|l|c|}
\hline 1. & Profit before tax as per IFRS (IFRS PBT) & 895,014 \\
\hline 2. & IFRS PBT adjusting items (a+b) & $-36,909$ \\
\hline a. & Other income taxes (local business tax, innovation tax, etc.) & $-33,645$ \\
\hline b. & IFRS adjustments & $-3,264$ \\
\hline 3. & Adjusted profit before tax (APBT) (Lines 1+2) & 858,105 \\
\hline 4. & Total APBT adjustments - not including Line 5 & $-559,364$ \\
\hline 5. & IFRS transition difference & $-9,459$ \\
\hline 6. & Tax base (Lines 3+4+5) or minimum income & 286,542 \\
\hline 7. & Corporate tax payable or minimum tax & 20,815 \\
\hline
\end{tabular}

Source: Authors processing based on data of Tóth-Takács (2018) 


\section{RESULTS}

From the results of the cleaned data, it is obvious that from the first year of the transition to IFRS, i.e. from 2017, the average tax rate of public listed companies has considerably decreased. It must, however, be examined whether it comes from the transition or other processes could also contribute to the considerable decrease experienced in 2017.

An explanation for the decrease can, on the one hand, be that from 2017 the rate of corporate tax has changed. As opposed to the progressive taxation applied before (the rate of the corporate tax was $10 \%$ up to a tax base HUF 500 million and $19 \%$ after that), a fixed rate $9 \%$ corporate tax was introduced. Thus, in order to make the data for 2016 to be comparable with data from subsequent periods, it was justified to recalculate the corporate taxes for 2016 by the tax rate introduced in 2017. In 2016, the financial statements complied the Act on Accounting, and they also include a detailed breakdown of the calculation of the corporate tax; thus, the theoretical, $9 \%$ tax can be derived from these.

Table 4. The impact of the change in the nominal rates on the effective tax rate

\begin{tabular}{|l|c|c|c|c|}
\hline \multicolumn{1}{|c|}{ Tax base } & $\begin{array}{c}\text { Eff.tax_10- } \\
\mathbf{1 9 \%}\end{array}$ & $\begin{array}{c}\text { Eff.tax_9 } \\
\text { \% }\end{array}$ & $\begin{array}{c}\text { Change of } \\
\text { rate }\end{array}$ & $\begin{array}{c}\text { Change of tax } \\
\text { burden }\end{array}$ \\
\hline HUF 0-500 million & $4.41 \%$ & $2.60 \%$ & $-1.81 \%$ & $-43.53 \%$ \\
\hline HUF 500 million < & $7.68 \%$ & $6.91 \%$ & $-0.77 \%$ & $-10.00 \%$ \\
\hline Eff-CT tax_total & $6.72 \%$ & $5.64 \%$ & $-1.07 \%$ & $-16.84 \%$ \\
\hline $\begin{array}{l}\text { millionCleanef } \\
\text { CT_total }\end{array}$ & $5.76 \%$ & $4.73 \%$ & $-1.03 \%$ & $-17.92 \%$ \\
\hline
\end{tabular}

Although it seems to be an apparent explanation as the tax rate was reduced from $19 \%$ to less than its half, i.e. to $9 \%$, it is important to note, that out of the 17 companies with data relevant to 2016, there were only five whose tax base exceeded the HUF 500 million limits, accordingly, the remaining 12 companies could apply the lower, $10 \%$ tax rate for their entire tax base.

In this way, the tax burdens of the twelve companies with a tax base under HUF 500 million decreased by a mere $10 \%$ as a result of the recalculation of the data for 2016, while their effective tax rates have decreased by 0.77 -point percentage. For tax income, however, the figures for the five "key accounts", who in 2016 have accounted for $95 \%$ of the total amount of the tax liabilities of the above 17 companies are crucial. Their tax liabilities decreased by $43.53 \%$ on average, and their average effective tax rates from $4.41 \%$ to $2.6 \%$.

As shown in table 4, the impact of the tax rate reduction introduced in 2017 on the effective tax rates and the tax burdens of the companies is smaller than the decrease experienced in the year of transition. Thus, the change in the tax rates in itself could not result in a drop of the average effective tax rates of companies to almost the half in the year of transition compared to these in the preceding year, i.e. 2016.

Although to allow their comparison, all other profit taxes except corporate tax were already reclassified into the profit before tax; there are still differences that result from the different accounting approaches. The IFRS adjusting items in PBT are aimed to treat this difference. In order that their impact and efficiency could be examined, we had to compare the pre-tax profits computed in two different ways. We can use as a point of reference the pre-tax profits for the year 2016. 
IFRS 1 requires the presentation of the data for the business year preceding transition for comparative purpose, in the first financial statements prepared based on International Financial Reporting Standards. Thus, the financial statements of those who transitioned in 2017 also include the comparative data for 2016. In these, we can find the profit before tax for 2016 that shall be adjusted as aforesaid by the other income taxes accounted for in the income tax expenses.

We compared the two types of data of those listed companies whose calculated pre-tax profits and corporate tax liabilities had a positive value in 2016 both in IFRS, and HAS. 15 of the 34 companies (seven listed on BUX and eight other traders) met this criterion. Using the data, we examined how the difference between the pre-tax profits estimated according to the IFRS and by the method prescribed by the Hungarian Act on Accounting impacted the average effective tax rate.

Table 5. Theoretical impact of the average effective tax rate change in 2017 on 2016

\begin{tabular}{|l|c|c|c|}
\hline & \multirow{2}{*}{$\begin{array}{c}\text { Av_diff.PTP } \\
\text { (Act on Acc./IFRS) }\end{array}$} & IFRS 2016 & Act on Acc. 2016 \\
\cline { 3 - 4 } & $+27.93 \%$ & Eff.tax rate & Eff.tax_10-19\% \\
\hline Other & $+14.77 \%$ & $2.52 \%$ & $7.97 \%$ \\
\hline BUX & $+21.79 \%$ & $5.17 \%$ & $2.89 \%$ \\
\hline
\end{tabular}

From Table 5, it is apparent that, on average, the IFRS profit before taxation is higher than in HAS. It is not only valid for the averages but also the single companies: as a result of the IFRS transition, the PBT decreased by only three companies, out of the 14 examined companies.

We also further examined other IFRS tax adjustments from the data of the national tax authority (Tóth-Takács, 2018), presented in Table 3. The total IFRS adjustments, other than the other income tax corrections, result in a much lesser decrease in the IFRS profit before tax. On the level of the adjusted PBT, essential adjustments are the adjusting effects of the transition differences. If we examine their increasing or decreasing impact on the tax base separately, then they are relatively significant. If, however, we consider them on their net values, their impacts amending the tax base become less significant compared to the other adjusting items associated with the IFRS.

Following their transitions to the IFRS, these companies have, as a non-recurring effect, a transition difference. According to IFRS 1, transition difference is accounted for directly in the equity; therefore, it does not affect the profit or loss. Although this difference is accounted for within equity, according to the Act on Personal Income Tax, it is still considered as an adjusting item of the tax base. According to the 2017 data, the predominant part of the transitioning companies availed themselves of the opportunity to decrease their tax base by the transition differences. The negative difference can be accounted for as a decreasing item in three years, while the positive difference can either be accounted for in three years or all in one sum, in the year of transition. The transition difference is a one-off effect in the tax of the IFRS companies. The adjusting effect of the transition difference ceases in the third year, at the latest, following the transition, and from then on it causes no difference compared to the tax determination of companies of the Hungarian Act on Accounting.

There are also adjusting items which both affect IFRS and the Hungarian Act on Accounting companies; however, the adjustment affects the two circles differently: e.g. IFRS companies 
more frequently use fair value measurement in their financial statements than local GAAP companies.

Among the examined companies, there were several holding companies, participants of the real estate market and financial services providers; by whom fair value measurement is a usual accounting practice, the impacts may cause a significant difference in the pre-tax profits of the two accounting systems.

By 2016, compared to the local GAAP, the pre-tax profit items were extended according to IFRS. Among the real estate companies, the profit before tax as per the IFRS was always higher than per local GAAP. During 2016 a steady price growth could already be observed on the real estate market (MNB Lakásárindex, 2020; Statisztikai Tükör, 2019), then this price increase could manifest through the fair valuation in the IFRS pre-tax profits. These surplus profits appear as a decreasing item in the tax base by the same amount as the profits originating from the fair valuation.

Thus, due to the adjusting items, the fair valuation had no impact on the amount of the corporate tax. It, however, decreased the effective tax rate calculated from the pre-tax profits obtained according to the IFRS.

\section{CONCLUSION}

In our paper, we examined corporate tax data obtained from the financial statements of Hungarian companies listed on the Stock Exchange. Our research question focused on the tax revenues of IFRS companies after the transition.

In Hungary, IFRS companies may use the profit before tax presented according to the international standards as the basis for the calculation of their corporate taxes.

In Hungary, the corporate tax base is determined on a domestic accounting basis. IFRS companies apply tax base adjusting items, taking into consideration also the domestic adjusting items and tax benefits.

According to data regarding share issuers listed on the Budapest Stock Exchange, in the year of transition, i.e. in 2017, the average effective tax rates of the companies decreased significantly, and this lower value also remained in 2018, i.e., the year following the transition. The decrease was larger than the considerable decrease in 2017 of the nominal corporate tax rate.

The PBT adjustments and the recognition of the transition differences also explain the decrease of the effective tax rate. The tax base adjustments secured the steadiness of tax revenues and the tax neutrality of taxpayers.

We identified the adjustments resulting from the fair value method as significant adjusting items by financial services providers, real estate and holding companies. The elimination of the positive effects of fair valuation on the profit before tax led to a considerable decrease in the effective tax rate but not in the tax revenue of the state.

In 2017, several impacts had resulted in a lower effective tax rate. These are partly attributable to transitioning to the IFRS and partly to the change of the tax rate. Their cumulative effect is the reason for the decrease. Although, by 2018, the average effective tax rate has increased, 
still, it did not reach its level of 2016. Thus, part of the decreasing impacts has remained, but the one-off tax-reducing effect of transition difference was less significant. The change in the effective tax rate was not the result of the fact that due to transitioning, the tax payment liabilities of the companies have decreased.

Due to the transition, the change in the effective corporate tax rate is significant. The results show significant differences in the pre-tax profits calculated under the two different accounting systems. If the tax law regulations would not treat this difference then the effective tax rate would remain unchanged. The adjustment rules secure the tax revenue of the state and the neutrality of the taxpayers.

The study cover, however, only the data of the year of transitioning (2017) and the consecutive business year; therefore, the impact on the long run cannot be ascertained. Results referring to FY 2020 shall be highly interesting because of the trends contrary to those that have existed during the studied period.

\section{REFERENCES}

Bíró, J. (2015). IFRS áttérés az egyedi beszámolók tekintetében. A törvényi szabályozás állása és az áttérési szabályok [IFRS Transition from Separate Financial Statements Perspective. Legal position and the Laws of the Transition.]. MKVK conference paper.

Borók T. (2015). Az IFRS-ek miatt szükséges változások a társasági adóban és az energiaellátók jövedelemadójában [Necessary Changes in Corporate Income Tax and Energy Supplier Tax Due to IFRS]. Számvitel, adó, könyvvizsgálat. 57(10), 455-457.

Brüggemann, U., Hitz, J. M., \& Sellhorn, T. (2013). Intended and unintended consequences of mandatory IFRS adoption: A review of extant evidence and suggestions for future research. European Accounting Review, 22(1), 1-37.

Cuzdriorean, D. D., \& Matis, D. (2012). The relationship between accounting and taxation insight the European Union: The influence of the international accounting regulation. Annales Universitatis Apulensis: Series Oeconomica,14(1), 28.

Eberhartinger, E., \& Klostermann, M. (2007). What if IFRS were a Tax Base? New Empirical Evidence from an Austrian Perspective. Accounting in Europe, 4(2), 141.

Gavana, G., Guggiola, G., \& Marenzi, A. (2015). Aligning taxation and international financial reporting standards: evidence from Italian listed companies. Politica Economica, 31(1), 77-96.

Guggiola, G. (2010). IFRS adoption in the EU, accounting harmonisation and markets efficiency: a review. International Business \& Economics Research Journal (IBER), 9(12).

Haverals, J. (2007). IAS/IFRS in Belgium: Quantitative analysis of the impact on the tax burden of companies. Journal of International Accounting, Auditing and Taxation, 16(1), 69-89.

Jacobs, O. H., Spengel, C., Stetter, T., \& Wendt, C. (2005). EU company taxation in case of a common tax base: A computer-based calculation and comparison using the enhanced model of the European Tax Analyser. Intertax. 33, 414.

Jirásková, S. (2013). Range data reported to the requirements of the IAS 12 and impact of the IFRS adoption for tax purposes in the tax collection of the Czech Republic. Acta Universitatis Agriculturae et Silviculturae Mendelianae Brunensis. 61(4), 961-966.

Mészáros L. (2015): A kormány döntött az IFRS-ek egyedi beszámolási célokra történő alkalmazásáról. Számvitel, adó, könyvvizsgálat. 57(6), 276-278. 
Molnár, Cs. (2015). Döntés-előkészítő folyamat az IFRS-ek hazai bevezetésére [Process of Preparation of the Domestic IFRS Transition]. Számvitel, adó, könyvvizsgálat. 57(2), 6567.

Procházka, D., \& Molin, J. (2016). Book-tax conformity: the review of recent research and its implication for the IFRS adoption in Europe. eJTR, 14, 96.

Tóth-Takács G. (2018). Az IFRS-alkalmazók 2017. évi társasági adó-adatai [Corporate Income Tax Data of IFRS Taxpayers 2017]. Számvitel, adó, könyvvizsgálat. 60(9), 19-21. 